\title{
"I wouldn't want to get on the bus": Older Adult Public Transit Use and Challenges during the COVID-19 Pandemic
}

\author{
Lea Ravensbergen ${ }^{1}$ (D), Bruce Newbold ${ }^{1}$ (D) \\ ${ }^{1}$ School of Earth, Environment \& Society, McMaster University \\ Keywords: public transportation, older adults, covid-19 \\ https://doi.org/10.32866/001c.18202
}

Findings

\begin{abstract}
This paper reports on older adult $(65+)$ public transit users' experiences during the COVID-19 pandemic, a group more vulnerable to severe illness from the virus. Drawing on semi-structured interviews with public transit users in Hamilton, Ontario, results highlight inequalities between those with access to a car and those dependant on transit. Further, we examine the impact of the policies taken to reduce viral transmission on the City's buses. For instance, boarding from back doors is physically strenuous for those with declining mobility. We conclude by stressing the importance of public transit, an essential service for many older adults.
\end{abstract}

\section{Research Questions}

Public transit use has been greatly affected by the COVID-19 pandemic (Statistics Canada 2020; Van Dongen 2020). Many transit agencies experienced a sharp decrease in ridership (and resulting loss in revenue) alongside a costly re-organization of services in response to public health recommendations (Statistics Canada 2020; Van Dongen 2020). Perhaps unsurprisingly, the equity implications of this pandemic on travel have already been brought to light (Deng, Messacar, and Morissette 2020; DeWeese et al. 2020). Not everyone has the option of staying home, nor of switching to travel modes that are lower-risk but more costly (driving, taxis) or energy-intensive (walking, cycling). Further, not everyone experiences the same risk. Notably, the risk for severe illness from COVID-19 increases with age (Government of Canada 2020). Given this, this paper explores the impact of the COVID-19 pandemic on older adult public transit users. Specifically, it answers the following research question: How has COVID-19 impacted older adults' mobility and experiences using public transportation?

\section{Methods and Data}

To answer these research questions, semi-structured interviews were completed over the phone between March and August 2020. To be eligible, participants had to be 65 years of age or older, live in Hamilton, and have used the City's Hamilton Street Railway (HSR) bus system since January $1^{\text {st }} 2020$ or be registered for the HSR's Accessible Transportation Services (ATS), which include DARTS, a fully accessible door-to-door transportation service, and a discount taxi fare program. Recruitment was done through community organization's listservs, posters on the City of Hamilton's official poster kiosks, and through snowball sampling. 
Thirty-one participants completed interviews discussing the impacts of COVID-19 (24 bus and 12 ATS ( 5 used both)). The research project's primary goals were to explore older adults' experiences using public transportation, however, an ethics amendment was submitted to ask participants the openquestions: "Has your travel changed at all in light of the current public health situation? If so, how?". All interviews were transcribed verbatim and systematically coded to distill the data into key themes reported herein.

\section{Findings}

COVID-19 meant social isolation and heavily restricted travel was rampant: "I feel like I'm a prisoner in bere" (F10) and "I'm in the incredibly lonely category" (F12). This isolation and heavy restriction was due to participant's awareness that they were part of a high-risk population: "I just don't go out. Because I don't want to be near anybody. I'm really compromised, so if I catch it... I'm gonna die." (F8).

Some of this isolation was due to a lack of safe travel options. For instance, F10 had no safe and feasible way of getting to the grocery store: "I could walk to the grocery store and they have a special hour for seniors in the morning [...] I couldn't carry much home if I was walking so that's the thing. And I wouldn't want to get on the bus" (F10). Here, large discrepancies emerged between older adults who use public transport by choice and those dependent on the service to meet their daily needs. Those older adults who had other mobility options (e.g., access to a car) shifted their travel mode. In fact, most of those who continued to ride public transit once the pandemic was declared did not own or have access to a car $(n=10$ of 12$)$. Those who did not have a car either relied on informal networks, such as friends and family, or continued to use public transit to meet their essential mobility needs even though many did not feel safe. For instance, for F10, discussed above, her children delivered groceries to her door while F17, who could no longer afford owning and maintaining a car, continued to use the bus: "I mean that's just where I don't have a choice, right?".

Half of those who usually ride public transit continued to do so once the pandemic was declared $(n=12$ of 24$)$, these participants were probed on how the services had changed due to the policies taken to reduce viral transmission on the bus service, which included additional cleaning measures, limiting the number of passengers on a bus, allocating seating in a distanced way, running on a reduced schedule, making passengers enter and exit from the rear doors only (fares were abolished), and requiring the use of non-medical masks (Table 1). The implementation of some of these measures exacerbated some of the challenges associated with using public transit as an older adult (Table 1). Most of those who continued to use the bus were understanding of these policies, even if it resulted in more challenging travel, given the unprecedent circumstances. However, transit agencies should be aware of, and when possible plan around, the negative impact of these policies on older adult riders, such as difficulty waiting longer periods of time for a bus (due to the passenger- 
Table 1. Challenges Reported by Older Adults during COVID-19

\begin{tabular}{|c|c|c|c|c|}
\hline Policy & Timeframe & Challenge & $\mathrm{N}$ & Examples \\
\hline \multirow{2}{*}{$\begin{array}{l}10 \\
\text { person } \\
\text { limit on } \\
\text { buses (15 } \\
\text { on } \\
\text { elongated } \\
\text { buses) }\end{array}$} & \multirow[t]{2}{*}{$\begin{array}{l}04-03-2020^{i} \\
06-22-2020^{i i}\end{array}$} & $\begin{array}{l}\text { Difficulty } \\
\text { standing due } \\
\text { to longer } \\
\text { wait times }\end{array}$ & 5 & $\begin{array}{l}\text { "it's just that they cut it down to } 10 \text { people. [...] So, I could be } \\
\text { standing there for God knows how long before I can get on the } \\
\text { bus...that's the only thing that's kept me home..." (F13) }\end{array}$ \\
\hline & & $\begin{array}{l}\text { Unsafe } \\
\text { distanced } \\
\text { seating } \\
\text { design }\end{array}$ & 4 & $\begin{array}{l}\text { "the person that did the bungee cords and red tape and signage } \\
\text { inside these buses was a complete twit [...] one of these seven } \\
\text { seats that's available is right beside the back door [...] So I come in } \\
\text { the back door and there's a person in one of seven seats about two } \\
\text { feet from me" (F12). }\end{array}$ \\
\hline \multirow[t]{2}{*}{$\begin{array}{l}\text { Boarding/ } \\
\text { exiting } \\
\text { from the } \\
\text { back } \\
\text { doors }\end{array}$} & \multirow[t]{2}{*}{$\begin{array}{l}\text { 03-19-2020 } \mathrm{iii}_{-} \\
07-01-2020^{\mathrm{iv}}\end{array}$} & $\begin{array}{l}\text { Difficulty } \\
\text { physically } \\
\text { boarding/ } \\
\text { exiting }\end{array}$ & $2^{1}$ & "but the back [boarding]; oh my God, it was a challenge..." (F18) \\
\hline & & $\begin{array}{l}\text { Joyriders } \\
\text { due to } \\
\text { temporarily } \\
\text { free service }\end{array}$ & 4 & $\begin{array}{l}\text { "Cuz people were getting on the bus and riding all around for } \\
\text { free...and there were drunks on the bus; more so than ever, and } \\
\text { there were drug addicts on the bus. I know: I was on those buses, I } \\
\text { wouldn't say it otherwise..." (F9) }\end{array}$ \\
\hline $\begin{array}{l}\text { Non- } \\
\text { medical } \\
\text { masks } \\
\text { required }\end{array}$ & $\begin{array}{l}\text { 06-22- } 2020 \mathrm{ii}_{-} \\
\text {present }\end{array}$ & $\begin{array}{l}\text { Safety issues } \\
\text { due to lack } \\
\text { of } \\
\text { enforcement }\end{array}$ & 5 & $\begin{array}{l}\text { "They say the masks are mandatory. But there are still people } \\
\text { getting on the buses without masks. And for this to work, } \\
\text { everybody has to have a mask." (F15) }\end{array}$ \\
\hline $\begin{array}{l}\text { Reduced } \\
\text { schedule }\end{array}$ & $\begin{array}{l}03-23-2020^{i i i} \\
09-06-2020^{v}\end{array}$ & $\begin{array}{l}\text { Longer wait } \\
\text { times }\end{array}$ & 2 & $\begin{array}{l}\text { "It just put me right over the top because they went to the } \\
\text { Saturday schedule" (F12) }\end{array}$ \\
\hline
\end{tabular}

${ }^{1}$ Though only two participants discussed boarding the bus from the back in relation to COVID-19, 22 of the 24 bus riders discussed how boarding or exiting from the back of the bus was more difficult for them due to their declining mobility (unlike the front, drivers cannot lower the bus at the back door)

${ }^{i}$ City of Hamilton (2020). COVID-19: HSR Service Update. Retrieved October 2020 from: https://www.hamilton.ca/government-information/news-centre/ news-releases/covid-19-hsr-service-update

${ }^{i i}$ City of Hamilton (2020). COVID-19 Update: Updates from the City of Hamilton. Retrieved October 2020 from: https://www.hamilton.ca/governmentinformation/news-centre/news-releases/covid-19-update-updates-city-hamilton-25

${ }^{i i i}$ City of Hamilton (2020). COVID-19 Update: Loading HSR buses through rear doors. Retrieved October 2020 from: https://www.hamilton.ca/governmentinformation/news-centre/news-releases/covid-19-update-loading-hsr-buses-through-rear

${ }^{i v}$ Hamilton Street Railway (2020, July $6^{\text {th }}$ ). HSR, Trans-Cab and DARTS has resumed fare collection. Operator compartment bio-shields have been installed as an additional measure to protect operators and customers, as all customers return to front door loading [Tweet]. https://twitter.com/hsr/status/ $1280147741893464067 /$ photo/1.

${ }^{v}$ At least, for most routes, see: City of Hamilton (2020). Service Changes Beginning September 6, 2020. Retrieved October 2020 from: https://www.hamilton.ca/ hsr-bus-schedules-fares/schedule-routes-maps/service-changes-beginning-september-6-2020

limit on buses and the reduced bus schedule), the challenges of boarding the bus using the back doors, and safety issues (due poorly planned seating design and the lack of enforcement of the mask requirement).

Half of the respondents registered for ATS continued using these services during the pandemic ( $n=6$ of 12), all of which expressed high travel satisfaction. Specifically, the buses only picked up one passenger at a time to reduce the risk of spreading the virus. This resulted in not only safe, but more efficient and enjoyable rides. This result highlights that expanding ATS to serve a wider range of seniors, though costly, may provide safe and accessible mobility to a vulnerable population during the COVID-19 pandemic.

Finally, the interviews also highlighted that public transportation is an essential service. Even amongst those most vulnerable to the virus, many rely on public transportation to meet their daily needs. A common concern amongst 
participants was that Hamilton's public transit agency would have to reduce or cut services, or eliminate discounted fares for seniors in response to lost revenues: "I think it's more difficult for them now, because they only allow 1 person at a time... But I think all in all, m'am, I would be lost without DARTS..." (F19). Because these services are so essential, Hamilton must ensure its continued investment in public transportation if it truly aspires to be an agefriendly city.

\section{Acknowledgements}

We would like to thank the older adults who participated in this study during this difficult time. Further, we would like to acknowledge funding from the McMaster Institute for Research on Aging.

Submitted: October 29, 2020 AEDT, Accepted: December 04, 2020 AEDT

This is an open-access article distributed under the terms of the Creative Commons Attribution 4.0 International License (CCBY-SA-4.0). View this license's legal deed at https://creativecommons.org/ licenses/by-sa/4.0 and legal code at https://creativecommons.org/licenses/by-sa/4.0/legalcode for more information. 


\section{REFERENCES}

Deng, Z., D. Messacar, and R. Morissette. 2020. "Running the Economy Remotely: Potential for Working from Home during and after COVID-19." STATCAN COVID-19: Data to Insights for a Better Canada, No.00026. Statistics Canada Catalogue No. 45280001. Ottawa: Statistics Canada.

DeWeese, James, Leila Hawa, Hanna Demyk, Zane Davey, Anastasia Belikow, and Ahmed Elgeneidy. 2020. "A Tale of 40 Cities: A Preliminary Analysis of Equity Impacts of COVID-19 Service Adjustments across North America." Findings, June. https://doi.org/10.32866/ $\underline{001 c .13395 .}$.

Government of Canada. 2020. "Coronavirus Disease (COVID-19): Prevention and Risks.” https://www.canada.ca/en/public-health/services/diseases/2019-novel-coronavirus-infection/ prevention-risks.html.

Statistics Canada. 2020. "Urban Public Transit Operating Revenue and Passenger Trips.” https://www150.statcan.gc.ca/n1/daily-quotidien/200831/cg-d001-eng.htm.

Van Dongen, M. 2020. "Transit in the Age of COVID-19: Will You Get Back on the HSR Bus?" The Hamilton Spectator, June 5, 2020. https://www.thespec.com/news/council/2020/06/05/ transit-in-the-age-of-covid-19-will-you-get-back-on-the-bus.html. 